\title{
Research on the Influence of Customer Value on Purchase Intention based on Service-dominant Logic
}

\author{
Pietro Schipani \\ University of Turin, Italy \\ pietro.schipani@gmail.com
}

\begin{abstract}
Creating more value is the source of a company's competitive advantage, and how to improve customer value is an important issue that the business community pays attention to. This study takes customer value co-creation participation behavior as the research object, introduces customer experience, explores the mechanism of customer value co-creation participation behavior on purchase intention, and uncovers the black box of customer value co-creation participation behavior to purchase intention. This research uses questionnaire analysis, introduces customer experience, and conducts research on the influence mechanism of customer co-creation value participation behavior on purchase intention. This article explores the specific composition and result mechanism of customer value co-creation behavior, which is conducive to further improving the theory of customer value co-creation behavior; explores the formation mechanism of purchase intention from the perspective of value co-creation, and provides a new theoretical reference for the promotion of purchase intention; How to improve customer value and co-creation effect in management practice, enhance customer purchase intention and provide decision support.
\end{abstract}

Keywords: Customer value, Customer willingness, Service leading logic, Influence mechanism

\section{Introduction}

Creating more value is the source of corporate competitive advantage [1]. The traditional view is that enterprises create value independently, and customers only act as value users [2]. However, the service-dominant logic believes that customers, enterprises, and other stakeholders are all resource integrators and can participate in the creation of value. Value is generated by the interaction between resource integrators, and value co-creation arises at the historic moment [3][4]. Customers play a core role in value creation, and their value co-creation behavior is considered to be an important way to build a company's core competitiveness and has received extensive attention from academia and business circles. At present, the related research of scholars is still in its infancy, mainly focusing on the elaboration and analysis of the overall theory, but there is a lack of in-depth research on the composition of customer value co-creation behavior and its result mechanism. Customer value co-creation behaviors are divided into roles within and outside roles.

Co-creation of customer value arises from joint production and develops from service-led logic. The traditional view of value creation believes that value is created independently by

Article history:

Received (January 28, 2019), Review Result (March 10, 2019), Accepted (April 9, 2019) 
enterprises, which is a study based on commodity-led logic. However, Wikström pointed out that customers can participate in the production and service of goods, bringing value to the enterprise and itself [5]. On this basis, Ramirez proposed the concept of value co-production, pointing out that enterprises and customers generate value through interaction, value creation has the characteristics of interaction and synchronization, and further clarified the concept of co-creating value between enterprises and customers [6]. However, co-production emphasizes that customers participate in production in a limited area dominated by the enterprise, which has greater limitations. Vargo and Lusch pointed out that all economies are service economies, and goods and services should be unified to produce service-dominant logic. Under the serviceled logic, the scope of customer value co-creation is further expanded, and customers can participate in the entire link of product design, production, delivery, and consumption [7]. With the development of service-dominant logic, Vargo and Lusch have clarified the customer's dominant position in value co-creation. At the same time, the value co-creation network has evolved from the dual relationship between enterprises and customers to a larger social network. They also pointed out that all economic participants are resource integrators and can participate in the creation of value. The magnitude of value depends on the specific situation [8]. Customer value co-creation behavior can be divided into customer value co-creation participation behavior and customer value co-creation citizen behavior. Among them, customer value co-creation participation behavior is an in-role behavior and is a necessary condition for value co-creation. Customer value co-creation citizen behavior is an off-role behavior, not a necessary condition for value co-creation [9][10]. Yi and Gong divided the two dimensions. Among them, customer value co-creation participation behavior includes four dimensions: information search, information sharing, interpersonal interaction, and responsible behavior. Customer value co-creation civic behavior includes four dimensions: feedback, publicity, help, and tolerance [11].

In the 1970s, Alvin Tovler first proposed the term "experience" in "Future Impact" and pointed out that the experience industry will become a new pillar of economic development after the service industry. Pine and James H. Gilmore conducted a systematic study on the experience and pointed out that experience is a kind of beautiful feeling formed in individual consciousness, this feeling involves intelligence, physical strength, emotion or spirit, and other aspects [12]. For the understanding of customer experience, Schmitt believes that customer experience is an unforgettable activity created by companies through products and services around customer needs [13]. From the explanations of scholars, it can be seen that customer experience is gradually formed in the development of the commodity economy. With the improvement of consumption levels, the consumption structure has been further optimized. Customers not only value the functional characteristics of goods and services but also value the subjective feelings and unforgettable experiences brought by them. Experience needs gradually surpass material needs and become the dominant consumer demand. Pine and James H Gilmore divided the customer experience into four dimensions: entertainment, aesthetics, education, and escape according to the customer's integration into the scene. Schmitt uses neurobiology, philosophy, physiology, and other multidisciplinary theories to propose a strategic experience module, which divides customer experience from five dimensions, namely sensory experience, thinking experience, emotional experience, related experience, and action experience. This division method is recognized by most scholars.

Dodds et al. pointed out that the possibility of customers buying a certain product or service is their willingness to buy [14]. In the process of decision-making, customers must first identify their own needs, clarify the purpose of the purchase, collect information on this basis, formulate solutions, and make purchase decisions after evaluating and analyzing each plan. Purchase 
intention reflects the result of customer evaluation and analysis. Purchase intention is a kind of psychological activity generated by customers in the process of purchasing products or services. Mullet believes that customers' attitudes towards products, evaluation, and external factors are all important factors that affect purchase intentions [15]. Purchase intention can be measured by reconstruction intention, recommendation intention, and premium purchase intention [16][17].

\section{Research hypotheses}

\subsection{Customer value co-creation, participation behavior, and purchase intention}

Scholars have limited research on the relationship between customer value co-creation participation behavior and purchase intention. A few studies have shown that customer participation behavior may have a direct or indirect impact on purchase intention. Karen et al. researched customer participation in the service delivery process and found that customer participation is conducive to generating good word-of-mouth and recommendations [18], and word-of-mouth and recommendations are important sources for improving customers' purchase intentions. Jones and Sasser's research shows that customer satisfaction has a significant positive impact on the repurchase, good word of mouth, public recommendation, and other behaviors, which is conducive to the formation of purchase intention [19]. Based on the above analysis, this research proposes the following hypotheses:

$\mathrm{H}_{1}$ : Customer value co-creation participation behavior has a significant positive impact on customers' purchase intentions;

$\mathrm{H}_{1-1}$ : Information search has a significant positive impact on customers' purchase intentions;

$\mathrm{H}_{1-2}$ : Information sharing has a significant positive impact on customers' purchase intentions;

$\mathrm{H}_{1-3}$ : Responsible behavior has a significant positive impact on customers' purchase intentions;

$\mathrm{H}_{1-4}$ : Interpersonal interaction has a significant positive impact on customers' purchase intention.

\subsection{Customer value co-creation, participation behavior, and customer experience}

According to the service-oriented logic, both the customer and the enterprise are resource integrators, and the customer's value co-creation behavior interacts with the enterprise, which can bring a good experience to the customer [3]. In the process of value co-creation and participation, customers can interact with the company as a whole, and interact with the company as a whole by watching the company's advertising, understanding the company's business and public welfare activities, and knowing the company's brand. It can also conduct "point" interactions with employees, including consulting with employees, accepting products and services delivered by employees, etc., as well as point-to-point contacts and event interactions with employees. It can also interact with other customers by "intersection" and communicate and exchange information with other customers through online platforms or offline physical environments. Prahalad and Ramaswamy pointed out that high-quality interaction between customers and companies is conducive to allowing customers to obtain a unique experience and help the company gain a unique competitive advantage [20]. Some 
scholars have also reached similar conclusions. Based on the above analysis, this research proposes the following hypotheses:

$\mathrm{H}_{2}$ : Customer value co-creation participation behavior has a significant positive impact on customer experience;

$\mathrm{H}_{2-1}$ : Information search has a significant positive impact on customer experience;

$\mathrm{H}_{2-2}$ : Information sharing has a significant positive impact on customer experience;

$\mathrm{H}_{2-3}$ : Responsible behavior has a significant positive impact on customer experience;

$\mathrm{H}_{2-4}$ : Interpersonal interaction has a significant positive impact on customer experience.

\subsection{Customer experience and purchase intention}

Some scholars have researched the relationship between customer experience and purchase intention, and generally believe that customer experience is beneficial to increase purchase intention. Holbrook and Hirschman pointed out that the pleasure of customers' consumption behavior is helpful to guide consumers to choose corresponding products or services. Fun can come from the attributes of the product or service itself or the emotional resonance caused by the product or service. Two scholars confirmed through empirical analysis that the better the customer experience, the stronger the purchase intention [21]. Research by Ang et al. showed that in the service industry, good services received by customers can make customers feel happy and promote purchase behavior [22]. Based on the above analysis, this research proposes the following hypotheses:

$\mathrm{H}_{3}$ : Customer experience has a significant positive impact on purchase intention.

\subsection{The mediating role of customer experience}

According to the SOR theory, the external stimulus (S) affects the customer's perception (O), and after a series of psychological effects, it will have an impact on the customer's response (R) [23]. Among them, the response variable is the behavioral result presented by the customer after being affected by the stimulus variable or the body variable, which can be divided into internal response and external response. The inner reaction is manifested as the customer's attitude or willingness, while the outer reaction is manifested as the customer's approach and avoidance [24]. Customers create an external stimulus through value co-creation and participation behavior, which has an effect on customers' emotions, cognition, etc., enhances customer experience, and then has an impact on consumer behavior and increases customers' purchase intentions. Based on the above analysis, this research proposes the following hypotheses:

$\mathrm{H}_{4}$ : Customer experience plays an intermediary role between customer value co-creation participation behavior and purchase intention;

$\mathrm{H}_{4-1}$ : Information search plays an intermediary role between customer value co-creation participation behavior and purchase intention;

$\mathrm{H}_{4-2}$ : Information sharing acts as an intermediary between customer value co-creation participation behavior and purchase intention;

$\mathrm{H}_{4-3}$ : Responsibility acts as an intermediary between customer value co-creation participation behavior and purchase intention; 
$\mathrm{H}_{4-4}$ : Interpersonal interaction plays an intermediary role between customer value cocreation participation behavior and purchase intention.

\section{3. research methods}

\subsection{Research sample}

The sample data collection of this study uses a combination of electronic questionnaires and paper questionnaires. The subject of this survey is smartphone users. The reason for choosing this research object is that the smartphone penetration rate is high, and it is a high-involved product, and it is easy to collect information on customer co-creating value participation behavior and behavior results. Strictly control the distribution process of the questionnaire to ensure that the questionnaire has good reliability and validity. Before the questionnaire is issued, explain the purpose of the survey to the survey participants and declare that they will participate voluntarily. At the same time, to eliminate the concerns of the survey respondents in the process of answering, we promise to make the survey results anonymous. Before conducting the formal survey, this research conducted a small-scale pre-test, and the results showed that the questionnaire met the requirements of the formal test. A formal survey was conducted on this basis. A total of 200 formal questionnaires were issued, and 187 questionnaires were returned, with a recovery rate of $93.50 \%$. Among them, there were 169 valid questionnaires with a recovery rate of $84.50 \%$. The sample is mainly young, with customers under 40 accounting for $72.78 \%$.

\subsection{Research tools}

Research tools consist of scales that measure key variables. To ensure the reliability and validity of the scale, the scales used in this study are all mature scales, which are widely used by scholars in related fields. At the same time, this study made appropriate modifications to the scale based on the characteristics of smartphone products to make them more in line with research needs. Using a Likert five-point scale, from "1—completely non-conforming" to "5completely conforming".

Co-creation value participation behavior scale. According to the scale compiled by Yi and Gong, it includes four dimensions: information search, information sharing, responsible behavior, and interpersonal interaction. The Cronbach's $\alpha$ of the overall scale is 0.891 , and the Cronbach's $\alpha$ of the subscales of information search, information sharing, responsible behavior, and interpersonal interaction is $0.737,0.860,0.902,0.948$, respectively, which are all greater than the acceptable standard of 0.70 , indicating that the scale has good measurement reliability.

Customer experience scale. Modified according to the customer experience scale compiled by Schmitt, it includes 5 dimensions: sensory experience, emotional experience, thinking experience, action experience, and related experience [18]. The Cronbach's $\alpha$ of the overall scale is 0.944 , and the Cronbach's $\alpha$ of the sensory experience, emotional experience, thinking experience, action experience, and associated experience subscales are 0.904, 0.808, 0.844, $0.885,0.851$, respectively, which are all greater than the acceptable standard of 0.70 , indicating that the scale has good measurement reliability.

Intention to Purchase Scale. According to the purchase intention scale compiled by Dodds and Zeithaml, the Cronbach's $\alpha$ of the scale is 0.903, which shows good measurement reliability. 


\section{Data analysis and results}

\subsection{Common method deviation test}

Since the sample data collection in this study uses the same questionnaire and is collected at the same time point, there is a possibility of common method deviations. A feasible method is to use Harman's single factor test method. If the unrotated maximum factor variance explanation rate is less than $50 \%$, the common method deviation is not serious. This study uses this method to test the common method deviation. The results show that the unrotated maximum factor variance explanation rate is $46.14 \%$, which is lower than the standard of $50 \%$, indicating that the common method deviation of the sample data is not serious and can be used later.

\subsection{Validity test}

To evaluate the degree of measurement of key variables such as information search, information sharing, responsible behavior, interpersonal interaction, customer experience, and purchase intention, this study analyzed and tested the content validity and structural validity of the scale. Since the scale used in this study is a mature scale at home and abroad, which is widely used by scholars, the scale has good content validity. At the same time, this study uses AMOS21.0 to perform confirmatory analysis on the measurement model to test the structural validity of the scale. The results are shown in [Table 1]. It can be seen from [Table 1] that the six-factor model is in good agreement with the data, where $\neg 2=693.792$, TLI $=0.915$, $\mathrm{CFI}=0.927$, RMSEA $=0.071$, and this model is significantly better than other models. Therefore, the scale used in this study has good structural validity.

Table 1. Confirmation analysis results between variables

\begin{tabular}{|c|c|c|c|c|c|}
\hline Model & $\mathrm{X}^{2}$ & DF & TLI & CFI & RMSEA \\
\hline Six-factor model & 693.792 & 377 & 0.915 & 0.927 & 0.071 \\
\hline Five-factor model a & 767.72 & 382 & 0.898 & 0.911 & 0.078 \\
\hline Five-factor model b & 770.574 & 382 & 0.898 & 0.91 & 0.078 \\
\hline Five-factor model c & 894.23 & 382 & 0.865 & 0.882 & 0.089 \\
\hline Five-factor model d & 795.385 & 382 & 0.891 & 0.904 & 0.08 \\
\hline Five-factor model e & 1009.919 & 382 & 0.835 & 0.855 & 0.099 \\
\hline Five-factor model f & 945.907 & 382 & 0.852 & 0.87 & 0.094 \\
\hline Three-factor model g & 1046.715 & 389 & 0.83 & 0.848 & 0.1 \\
\hline Single-factor model h & 1495.293 & 392 & 0.717 & 0.745 & 0.129 \\
\hline
\end{tabular}

Note: $N=169$, the following is the same. A: Combine information search and information sharing into one factor; B: Combine information search and responsibility behavior into one factor; $C$ : Combine information search and interpersonal interaction into one factor; D: Combine information sharing and responsibility behavior into one Factor; E: Combine information sharing and interpersonal interaction into one factor; F: Combine responsible behavior and interpersonal interaction into one factor; G: Combine information search, information sharing, responsible behavior, and interpersonal interaction into one factor; H: Combine All variables are combined into one factor.

\subsection{Correlation analysis}

The correlation analysis of the variables is shown in [Table 2]. According to the data in the table, information search and purchase intention $(\gamma=0.553, \mathrm{p}<0.01)$, information sharing and purchase intention $(\gamma=0.452, \mathrm{p}<0.01)$, responsible behavior and purchase intention $(\gamma=0.490$, $\mathrm{p}<0.01=$, Interpersonal interaction and purchase intention $(=0.306, \mathrm{p}<0.01)$ both show a significant positive correlation, information search and customer experience $(\gamma=0.643, p<$ 
$0.01)$, information sharing and customer experience $(\gamma=0.608, \mathrm{p}<0.01) 0.01)$, responsible behavior and customer experience $(\gamma=0.579, \mathrm{p}<0.01)$, interpersonal interaction and customer experience $(\gamma=0.356, p<0.01)$ also showed a significant positive correlation, and customer experience and purchase intention also showed significant The positive correlation $(\gamma=0.675$, $\mathrm{p}<0.01$ ), the result provides a preliminary basis for the hypothesis verification.

\subsection{Hypothesis testing}

The hypothesis was tested using the hierarchical regression method, and the results are shown in [Table 3]. According to the data in the table, customer value co-creation participation behavior has a significant positive impact on purchase intention $(\beta=0.717, p<0.01), H_{1}$ is confirmed; customer value co-creation participation behavior has different effects on purchase intention. contribution. Among them, information search and responsible behavior have a significant positive impact on purchase intention $(\beta=0.532, \mathrm{p}<0.01 ; \beta=0.331, \mathrm{p}<0.01) . \mathrm{H}_{1-1}$ and $\mathrm{H}_{1-3}$ have been confirmed; information sharing and interpersonal interaction have a positive effect on purchase intentions $(\beta=0.532, \mathrm{p}<0.01 ; \beta=0.331, \mathrm{p}<0.01)$. There is no significant effect on purchase intention $\left(\beta=-0.111\right.$, ns; $\beta=-0.012$, ns), and $\mathrm{H}_{1-2}$ and $\mathrm{H}_{1-4}$ have not been confirmed.

Table 2. Correlation analysis results

\begin{tabular}{|c|c|c|c|c|c|c|}
\hline Variable & 1 & 2 & 3 & 4 & 5 & 6 \\
\hline 1.Information Search & 1 & & & & & \\
\hline 2.Information sharing & $0.740^{* *}$ & 1 & & & & \\
\hline 3.Responsible behavior & $0.554^{* *}$ & $0.720^{* *}$ & 1 & & & \\
\hline 4.Interpersonal interaction & $0.398^{* *}$ & $0.334^{* *}$ & $0.526^{* *}$ & 1 & & \\
\hline 5.Customer experience & $0.643^{* *}$ & $0.608^{* *}$ & $0.579^{* *}$ & $0.356^{* *}$ & 1 & \\
\hline 6.Intention to buy & $0.553^{* *}$ & $0.452^{* *}$ & $0.490^{* *}$ & $0.306^{* *}$ & $0.675^{* *}$ & 1 \\
\hline Mean (M) & 3.676 & 3.42 & 3.781 & 4.151 & 3.736 & 3.553 \\
\hline Standard deviation (SD) & 0.823 & 1.087 & 0.921 & 0.809 & 0.716 & 0.928 \\
\hline
\end{tabular}
Note: * represents a significant correlation at the 0.05 level (two-sided); ** represents a significant correlation at the 0.01 level
(two-sided).

Table 3. Hierarchical regression analysis results

\begin{tabular}{|c|c|c|c|c|c|c|c|}
\hline \multirow{2}{*}{ Variable } & \multicolumn{3}{|c|}{ Customer experience } & \multicolumn{3}{c|}{ Purchase Intention } \\
\cline { 2 - 7 } & Model 1 & Model 2 & Model 3 & Model 4 & Model 5 & Model 6 & Model 7 \\
\hline $\begin{array}{c}\text { Co-creating } \\
\text { participation } \\
\text { behavior }\end{array}$ & $0.669^{* *}$ & & $0.717^{* *}$ & $0.251^{*}$ & & & \\
\hline Information search & & $0.355^{* *}$ & & & & $0.532^{* *}$ & $0.294^{* *}$ \\
\hline Information Sharing & & 0.072 & & & & -0.111 & -0.159 \\
\hline $\begin{array}{c}\text { Responsible } \\
\text { behavior }\end{array}$ & & $0.206^{* *}$ & & & & $0.331^{* *}$ & $0.193^{*}$ \\
\hline $\begin{array}{c}\text { Interpersonal } \\
\text { interaction }\end{array}$ & & 0.016 & & & & -0.012 & 4.023 \\
\hline Customer experience & & & & $0.696^{* *}$ & $0.875^{* *}$ & & $0.670^{* *}$ \\
\hline$R^{2}$ & 0.475 & 0.488 & 0.325 & 0.476 & 0.455 & 0.36 & 0.496 \\
\hline F value & $150.916^{* *}$ & $39.148^{* *}$ & $80.254^{* *}$ & $75,452^{* *}$ & $139.567 * *$ & $23.035^{* *}$ & $32.125^{* *}$ \\
\hline$R^{2}$ value change & 0.475 & 0.488 & 0.325 & 0.152 & 0.455 & 0.36 & 0.137 \\
\hline F value change & $150.916^{* *}$ & $39.148^{* *}$ & $80.254^{* *}$ & $48.043^{* *}$ & $139.567^{* *}$ & $23.035^{* *}$ & $44.210^{* *}$ \\
\hline
\end{tabular}

Note: * represents a significant correlation at the 0.05 level (two-sided); ${ }^{* *}$ represents a significant correlation at the 0.01 level (two-sided). 
Customer value co-creation participation behavior has a significant positive impact on customer experience $(\beta=0.669, \mathrm{p}<0.01), \mathrm{H}_{2}$ is confirmed; customer value co-creation participation behavior has a large difference in the impact of various dimensions on customer experience. Among them, information search and responsible behavior have a significant positive impact on customer experience $(\beta=0.355, \mathrm{p}<0.01 ; \beta=0.206, \mathrm{p}<0.01)$, and $\mathrm{H}_{2-1}$ and $\mathrm{H}_{2-}$ 3 have been confirmed. However, the impact of information sharing and interpersonal interaction on customer experience is not significant ( $\beta=0.072$, ns; $\beta=0.016$, ns), $\mathrm{H}_{2-2}$ and $\mathrm{H}_{2-4}$ have not been confirmed. Customer experience has a significant positive impact on purchase intention $(\beta=0.875, \mathrm{p}<0.01)$, and $\mathrm{H} 3$ is confirmed.

After adding the mediating variable of customer experience, customer experience has a significant positive effect on purchase intention $(\beta=0.696, p<0.01)$. Customer value co-creation and participation behavior have a significant positive impact on purchase intention, but the positive impact is weakened $(\beta=0.251, \mathrm{p}<0.05)$. Therefore, customer value co-creation behavior has a partial mediating effect on purchase intention, and $\mathrm{H}_{4}$ has been partially confirmed.

Next, verify the mediating role of customer experience between the various dimensions of customer value co-creation and participation behavior, and purchase intention. According to the above analysis, since information sharing and interpersonal interaction have no significant impact on customer experience and purchase intention, the mediating effect of customer experience between information sharing and purchase intention, interpersonal interaction, and purchase intention does not hold. $\mathrm{H}_{4-2}, \mathrm{H}_{4-4}$ have not been confirmed. When examining the mediating effect of customer experience between information search and responsible behavior and purchase intention, after adding customer experience, customer experience has a significant positive impact on purchase intention $(\beta=0.670, p<0.01)$, information search, It has a significant positive impact on purchase intention, but the positive impact is weakened $(\beta=0.294, p<0.01)$, and responsible behavior has a significant positive impact on purchase intention, and the positive impact is also weakened $(\beta=0.193, p<0.05))$. Therefore, customer experience plays a partially intermediary role between information search and responsible behaviors and purchase intentions, and $\mathrm{H}_{4-1}$ and $\mathrm{H}_{4-3}$ have been partially confirmed.

To verify the results of the mediation effect, according to the research results of Shrout and Bolger, the Bootstrap program is used to test the significance of the mediation effect [25]. The results show that the 95\% confidence interval of the mediating effect between customer experience in information search and purchase intention is [0.25,0.54], and the $95 \%$ confidence interval of the mediating effect between customer experience between responsible behavior and purchase intention is $[0.21,0.49]$, Not including 0 . It shows that the mediating effect of customer experience between information search and responsible behavior and purchase intention is significant, and H4-1 and H4-3 have been further confirmed.

\section{Conclusion}

This study uses questionnaire analysis and introduces customer experience to study the influence mechanism of customer co-creating value participation behavior on purchase intention. The results found that: customer co-creating value participation behavior has a significant positive impact on purchase intention, and customer co-creating value subordinates Information searching and responsible behaviors in all dimensions have a significant positive impact on purchase intention, while information sharing and interpersonal interaction have no significant impact on purchase intention. Customer co-creation value participation behavior has a significant positive impact on customer experience. Information search and responsible 
behaviors in the subordinate dimensions of customer co-creation value have a significant positive impact on customer experience, while information sharing and interpersonal interaction have no significant positive impact on customer experience. influences. Customer experience plays a part in mediating the role between customer value co-creation and participation behavior and purchase intention. At the same time, customer experience also plays a part in the mediation role between information search and responsible behavior, and purchase intention. However, customer experience plays a part in information sharing, and interpersonal interaction, and purchase.

\section{References}

[1] A. F. Payne, K. Storbacka, and P. Frow, "Managing the co-creation of value," Journal of the Academy of Marketing Science, vol.36, no.1, pp.83-96, (2008)

[2] R. Normann and R. Ramirez, "From value chain to value constellation: Designing interactive strategy," Harvard Business Review, vol.71, no.4, pp.65-77

[3] S. L. Vargo and R. F. Lusch, "Service-dominant logic: Continuing the evolution," Journal of the Academy of Marketing Science, vol.36, no.1, pp.1-10, (2008)

[4] C. Grönroos and P. Voima, "Critical service logic: Making sense of value creation and co-creation," Journal of the Academy of Marketing Science, vol.41, no.2, pp.133-150, (2013)

[5] S. Wikström, “The customer as co-producer," European Journal of Marketing, vol.30, no.4, pp.6-19

[6] R. Ramirez, "Value co-production: Intellectual origins and implications for practice and research," Strategic Management Journal, vol.20, no.1, pp.49-65

[7] S. L. Vargo and R. F. Lusch, "Evolving to a new dominant logic for marketing. In the service-dominant logic of marketing," Routledge, pp.21-46, (2014)

[8] S. L. Vargo and R. F. Lusch, "Institutions and axioms: An extension and update of service-dominant logic," Journal of the Academy of Marketing Science, vol.44, no.1, pp.5-23, (2016)

[9] L. L. Bove, S. J. Pervan, S. E. Beatty, and E. Shiu, "Service worker role in encouraging customer organizational citizenship behaviors," Journal of Business Research, vol.62, no.7, pp.698-705, (2009)

[10] D. Levy, "Atoning for an indiscretion: The impact of reception, publicity, and censorship on the re-editing of stazione termini," The Italianist, vol.39, no.2, pp.251-266, (2019)

[11] H. Descamps and C. A. Thaiss, "Intestinal tolerance, with a little help from our microbial friends," Immunity, vol.49, no.1, pp.4-6, (2018)

[12] B. J. Pine and J. Gilmore, "The experience economy Harvard business school press," Boston: Massachusetts

[13] B. Schmitt, "Experiential marketing," Journal of Marketing Management, vol.15, no.1-3, pp.53-67

[14] W. Dodds, K.B. Monroe, and D. Grewal, "Effects of price, brand, and store information on buyers' product evaluations," Journal of Marketing Research, vol.28, no.3, pp.307-319

[15] G. M. Mullet and M. J. Karson, "Analysis of purchase intent scales weighted by the probability of actual purchase,” Journal of Marketing Research, vol.22, no.1, pp.93-96

[16] W. Boulding, A. Kalra, R. Staelin, and V. A. Zeithaml, “A dynamic process model of service quality: From expectations to behavioral intentions," Journal of Marketing Research, vol.30, no.1, pp.7-27

[17] A. Ahmed and J. Ghostlaw, "Diversifying rice-centric agriculture and diets: The Bangladesh experience," IFPRI book chapters, (2019)

[18] S. Coelho, M. Russo, R. Oliveira, "Sustainable energy action plans at city level: A Portuguese experience and perception," Journal of Cleaner Production, vol.176, pp.1223-1230, (2018)

[19] T. O. Jones and W. E. Sasser, "Why satisfied customers defect," Harvard Business Review, vol.73, no.6, pp.88

[20] C. K. Prahalad and V. Ramaswamy, "Co-creation experiences: The next practice in value creation," Journal of interactive marketing, vol.18, no.3, pp.5-14, (2004) 
[21] M. B. Holbrook and E. C. Hirschman, "The experiential aspects of consumption: Consumer fantasies, feelings, and fun," Journal of Consumer Research, vol.9, no.2, pp.132-140

[22] S. H. Ang, S. M. Leong, and J. Lim, "The mediating influence of pleasure and arousal on layout and signage effects: Comparing more and less customized retail services," Journal of Retailing and Consumer Services, vol.4, no.1, pp.13-24

[23] A. Mehrabian and J. A. Russell, “An approach to environmental psychology,” The MIT Press

[24] S. A. Eroglu, K. A. Machleit, and L. M. Davis, Empirical testing of a model of online store atmospherics and shopper responses," Psychology and Marketing, vol.20, no.2, pp.139-150, (2003)

[25] P. E. Shrout and N. Bolger, "Mediation in experimental and non-experimental studies: New procedures and recommendations,” Psychological Methods, vol.7, no.4, pp.422, (2002) 